\title{
Erwinia uredovora 20D3 Contains an IncM Plasmid
}

\author{
By GEORGES THIRY ${ }^{1 *}$ AND MICHEL FAELEN ${ }^{2}$ \\ ${ }^{1}$ Laboratoire de Génétique Moléculaire, Département de Botanique, Université de Liège, \\ Sart Tilman, B-4000 Liège, Belgium \\ ${ }^{2}$ Laboratoire de Génétique, Université de Bruxelles, B-1640 Rhode-St-Genèse, Belgium
}

(Received 30 December 1983; revised 27 February 1984)

Erwinia uredovora was lysogenized with phages Mucts62 and D108-1, a mini derivative of D108cts 10 carrying a $\mathrm{Cm}^{\mathrm{r}}$ marker. The 20D3(Mucts62)(D108-1) lysogen was induced and used as donor in a mating with a phage-resistant Escherichia coli; the $\mathrm{Cm}^{\mathrm{r}}$ marker was transferred to this recipient strain at low frequency. The analysis of the $\mathrm{Cm}^{\mathrm{r}}$ transconjugants indicated that they had acquired the pULG3 plasmid of $E$. uredovora associated with a D108-1 prophage. Subsequent transfer of these pULG3 derivatives within $E$. coli indicated that pULG3 was conjugative. Incompatibility experiments showed that pULG3 is a member of the IncM group.

\section{INTRODUCTION}

Erwinia uredovora belongs to the herbicola group of the genus Erwinia. These are yellow pigmented enterobacteriaceae, often isolated as epiphytes. The peculiarity of the uredovora species resides in their ability to destroy the uredia and urediospores of the rust fungus Puccinia (Buchanan \& Gibbons, 1974).

Recent work shows that E. uredovora 20D3: (i) produces a phage tail-like bacteriocin active against the phytopathogenic strains Erwinia carotovora and Erwinia amylovora (Thiry-Braipson et al., 1982); (ii) contains three plasmids with molecular sizes of $260 \mathrm{~kb}$ (pULG1), $216 \mathrm{~kb}$ (pULG2) and $88 \mathrm{~kb}$ (pULG3), with pULG1 involved in both yellow pigmented and thiaminindependent phenotypes (Thiry, 1984); and (iii) adsorbs and propagates the phages $\mathrm{Mu}$ and D108 (Faelen et al., 1981). Mu and D108 are mutator phages that are heteroimmune and closely related. The analysis of heteroduplexes between the DNA of the two phages indicates an homology of $95 \%$ between their genomes (Hull et al., 1978). Both phages are efficient transposable elements (for a review, see Toussaint \& Résibois, 1983). Mini-Mu and mini-D108 derivatives that have lost their lytic functions but conserved the ability to transpose were isolated (Faelen et al., 1978; Résibois et al., 1981). The frequency of transposition of miniphages that only provide the $A$ gene product is low but is strongly stimulated in the presence of a helper phage that can be either Mu or D108 (A. Toussaint, personal communication). Since the mini-phage and its helper each code for a thermolabile repressor, their transposition can be induced very efficiently at $42{ }^{\circ} \mathrm{C}$ and repressed at low temperature. Upon induction of a lysogen containing a mini $A^{+}$phage and a helper, both genomes are packaged and the lysate can be used to introduce the mini-phage into sensitive bacteria.

This paper reports the use of $\mathrm{Mu}$ and D108-1, a mini-D108 derivative carrying $\operatorname{Tn} 9$, to demonstrate that one of the plasmids of E. uredovora $20 \mathrm{D} 3$ is conjugative. The procedure involved: (i) the isolation of a lysogen carrying D108-1 and Mucts62 helper phage; (ii) the induction of the prophages resulting in the transposition of Mucts62 and D108-1 to random locations in the genome of 20D3; and (iii) selection for the conjugative transfer of the $\mathrm{Cm}^{\mathrm{r}}$ marker of D108-1 by mating the induced lysogen with an appropriate recipient. 


\section{METHODS}

Bacteria, phages and plasmids. These are listed in Table 1. All plasmids are maintained in Escherichia coli C600 Rif.

Media. Bacteria and phages were grown in L broth (Miller, 1972). Mu and D108 lysates were titrated on L agar (L broth containing $1 \cdot 2 \%, w / v$, agar). Minimal medium was M9 (Miller, 1972) with $0 \cdot 2 \%(w / v)$ glucose. The Lac phenotype was tested on MacConkey agar supplemented with $1 \%(w / v)$ lactose. Antibiotics were used at $20 \mu \mathrm{g} \mathrm{ml}^{-1}$ for ampicillin (Ap), tetracycline (Tc), chloramphenicol (Cm) and kanamycin ( $\left.\mathrm{Km}\right), 50 \mu \mathrm{g} \mathrm{ml}{ }^{-1}$ for streptomycin (Sm) and rifampicin (Rif), and $100 \mu \mathrm{g} \mathrm{ml}^{-1}$ for spectinomycin (Sp). The sulphonamide (Su), neomycin $(\mathrm{Nm})$ and trimethoprim $(\mathrm{Tp})$ markers were tested with sensitivity discs obtained from l'Institut Pasteur, Paris, France. Phages were diluted in SM buffer (Tris/ $\mathrm{HCl}, 10^{-2} \mathrm{M} ; \mathrm{NaCl}, 10^{-1} \mathrm{M} ; \mathrm{MgSO}_{4}, 2 \times 10^{-2} \mathrm{M}, \mathrm{pH} 7 \cdot 4$ ) and bacteria in $\mathrm{MgSO}_{4}, 10^{-2} \mathrm{M}$.

Preparation of phage lysates. Phage lysates were prepared by heat-induction of $E$. coli lysogens using the procedure of Bukhari \& Ljungquist (1977).

Lysogenization of $20 \mathrm{D} 3$ by Mucts62. A drop of Mucts62 lysate at $\sim 10^{9}$ p.f.u. $\mathrm{ml}^{-1}$ was spotted on a lawn of 20D3 on $\mathrm{L}$ agar and incubated overnight at $32^{\circ} \mathrm{C}$. Bacteria from the lysis area were streaked on $\mathrm{L}$ agar. Isolated colonies were tested for the presence of Mu prophage by stabbing into a lawn of sensitive bacteria on $\mathrm{L}$ agar. Lysogenic bacteria produced phages which lysed the indicator lawn.

Mating. Spot matings were done as described by Miller (1972).

Preparation and analysis of plasmid DNA. Large-scale DNA preparations were made according to Currier \& Nester (1976). Two types of small-scale extractions were used. The first was the mini-preparation of Kado \& Liu

\section{Table 1. Bacterial strains, phages and plasmids}

The symbols of bacterial genes are according to Bachmann (1983) and of plasmid markers according to Novick et al. (1976).

\section{Strain}

E. uredovora

20D3

20D3(Mucts62)

20D3(Mucts62)(D108-1)

E. coli

JM260

\section{JMM260}

CSH23

MXR

C600

C600 Rif

Phage

Mucts62

D108cts 10

DM1

D108-1

Characters

Source or reference

Prototroph

As 20D3 with (Mucts62)

As 20D3 with (Mucts62)(D108-1)

$\Delta$ (ara-leu) his argE lac gal mtl xyl recB sbcB rpsL supE hsr hsm ${ }^{+}$

As JM260 but $\mathrm{Mu}^{\mathrm{r}}$

$\Delta$ (pro-lac) supE thi rpsE

$\Delta$ (pro-lac) galE thi rec $A$

thr leu thi lac $Y$ tonA supE

Spontaneous Rifr mutant of $\mathrm{C} 600$

Characters

Thermoinducible

Thermoinducible

Recombinant between D108cts 10

and $\mathrm{Mu}$; has D108 immunity and $\mathrm{Mu}$

host range

D108cts10 $\Delta(B-S)$ carrying a Tn9 in

the remaining part of the $S$ gene

$\left.\begin{array}{lll}\text { Plasmid } & \text { Inc group } & \multicolumn{1}{c}{\text { Marker }} \\ \text { RIP185 } & \text { B } & \text { Km Tp } \\ \text { R16a } & \text { C } & \text { Km Ap Su } \\ \text { Flac } & \text { FI } & \text { Lac } \\ \text { pIP24 } & \text { FII } & \text { Tc } \\ \text { R124drd2 } & \text { FIV } & \text { Tc } \\ \text { pIP523 } & \text { H1 } & \text { Tc } \\ \text { RIP112 } & \text { I } \alpha & \text { Km Nm } \\ \text { TP114 } & \text { I2 } & \text { Km } \\ \text { R721 } & \text { I } \delta & \text { Sm Tp } \\ \text { R69-2 } & \text { M } & \text { Km Ap } \\ \text { RP4 } & \text { P } & \text { Km Ap Tc } \\ \text { R135 } & \text { M } & \text { Tc }\end{array}\right\}$ Institut Pasteur, Paris, France

ATCC 19321, received from

C. Kado, Davis, USA

This work

This work

F. Sanchez, UNAM, Mexico

This work

Miller (1972)

Faelen et al. (1978)

Appleyard (1954)

P. Pohl, INRV, Belgium

Reference

Howe (1973)

Hull et al. (1978)

Toussaint et al. (1983)

Résibois et al. (1981)

Mergeay, Mol, Belgium 
(1981). The second was derived from the alkaline extraction procedure of Birnboim \& Doly (1979): an overnight culture in $\mathrm{L}$ broth $(20 \mathrm{ml})$ was centrifuged at $7000 \mathrm{~g}$ for $5 \mathrm{~min}$ at $4{ }^{\circ} \mathrm{C}$. The pellet was resuspended in $3 \mathrm{ml}$ of a lysis solution ( $2 \mathrm{mg}$ lysozyme $\mathrm{ml}^{-1}$, $50 \mathrm{mM}$-glucose, $10 \mathrm{mM}$-EDTA, $25 \mathrm{~mm}$-Tris/ $\mathrm{HCl}, \mathrm{pH} 8.0$ ) and placed on ice for $30 \mathrm{~min}$. A $1 \%(\mathrm{w} / \mathrm{v})$ SDS solution $(6 \mathrm{ml})$ in $0.2 \mathrm{M}-\mathrm{NaOH}$ was added. The tube was gently inverted, left for $5 \mathrm{~min}$ at $0{ }^{\circ} \mathrm{C}$ and $4.5 \mathrm{ml}$ of a renaturating solution ( $3 \mathrm{M}$-sodium acetate, $\mathrm{pH} 4.8$ ) added. The tube was then placed on ice for $1 \mathrm{~h}$. High molecular weight DNA and protein-SDS complexes were removed by centrifugation at $17000 \mathrm{~g}$ for $5 \mathrm{~min}$ at $4{ }^{\circ} \mathrm{C}$. Cloudy material that remained in the supernatant was removed by a second centrifugation at $20000 \mathrm{~g}$ for $5 \mathrm{~min}$ at $4{ }^{\circ} \mathrm{C}$. The plasmid DNA in the supernatant was precipitated with two volumes of cold ethanol for $30 \mathrm{~min}$ at $-20^{\circ} \mathrm{C}$, pelleted by centrifugation at $6000 \mathrm{~g}$ for $5 \mathrm{~min}$ at $4{ }^{\circ} \mathrm{C}$, and resuspended in $2 \mathrm{ml}$ of a solution containing $0.1 \mathrm{M}$-sodium acetate and $50 \mathrm{~mm}-\mathrm{Tris} / \mathrm{HCl}(\mathrm{pH} 8.0)$. After a second ethanol precipitation and centrifugation, the pellet was briefly dried in a vacuum desiccator, dissolved in $0.5 \mathrm{ml}$ pancreatic RNAase $\left(0.1 \mathrm{mg} \mathrm{ml}{ }^{-1}\right)$ in $5 \mathrm{~mm}$-Tris/ $\mathrm{HCl}(\mathrm{pH} 7.5)$ and incubated for $30 \mathrm{~min}$ at $37^{\circ} \mathrm{C}$. Plasmid DNA could be restricted at this step, although better results were obtained after a third ethanol precipitation. The DNA pellet was finally resuspended in $250 \mu \mathrm{l}$ TE buffer $(10 \mathrm{~mm}$-Tris/ $\mathrm{HCl}, 1 \mathrm{~mm}$-EDTA, $\mathrm{pH} 7 \cdot 8)$.

Electrophoresis of plasmid DNA was carried out in $0.7 \%(w / v)$ agarose horizontal slab gels $(140 \times 130 \times 3 \mathrm{~mm})$ in Tris/acetate buffer (McDonell $e t$ al., 1977) at $100 \mathrm{~V}$ for $6 \mathrm{~h}$ or, when the DNA was restricted, at $25 \mathrm{~V}$ for $16 \mathrm{~h}$. Gels were stained with ethidium bromide $\left(0.5 \mu \mathrm{g} \mathrm{ml}^{-1}\right)$ for $45 \mathrm{~min}$. The DNA was visualized and photographed on a UV transilluminator type C-63 (Lab Center, Belgium). Negatives were scanned with a 3CS Joyce-Loebl photomicroscope (Van Oortmerssem, Antwerpen, Belgium) and the relative amounts of DNA in the various restriction fragments were determined by measuring the area under the peaks. Restriction enzymes were obtained from Boehringer and used according to the instructions supplied.

Incompatibility tests. Tra ${ }^{+}$plasmids were transferred into appropriate strains. The unstable inheritance of two plasmids in the lineage of at least four different clones which possessed both molecules was tested as described by Datta (1979).

\section{RESULTS AND DISCUSSION}

\section{Isolation of 20D3(Mucts62)(D108-1) lysogens}

The genomes of Mu, D108 and DM1 (a hybrid between D108cts10 and Mucts62; Toussaint et al., 1983) contain an invertible DNA segment, the $G$ region, that carries genes specifying the host range of the phages (van de Putte et al., 1980; Gill et al., 1981). Erwinia uredovora 20D3 is sensitive to these three phages which have their host range specified by the G loop in the '- ' orientation (Faelen et al., 1981). Phage lysates that contained both $\mathrm{G}(-)$ and $\mathrm{G}(+)$ particles were prepared by heat induction of E. coli (Mucts62) or (DM1)(D108-1) lysogens and titrated on $E$. coli JM260 and E. uredovora 20D3. Both lysates gave 10 to 300 fewer plaques on 20D3 than on JM260 (see Table 2). The difference in the number of p.f.u. detected with the same lysate between these two hosts not only reflected a difference in the number of $G(-)$ and $G(+)$ particles in the lysates but also an incomplete protection of the phage DNA against the hostspecific restriction system of E. uredovora (Toussaint \& Schoonejans, 1982). 20D3(Mucts62) lysogens were isolated as described in Methods. One of the lysogens was purified, infected with a DM1/D108-1 lysate and plated on $\mathrm{L}$ agar supplemented with $\mathrm{Cm} . \mathrm{Cm}^{\mathrm{r}}$ colonies resulting from

\section{Table 2. Titration of Mucts62 and DM1/D108-1 lysates on E. coli JM260 and}

\section{E. uredovora $20 D 3$}

Phage lysates were prepared by heat-induction of $E$. coli lysogens, as described in Methods, and the number of transductants was determined by spotting dilutions of the lysate on lawns of the sensitive bacteria plated on L agar supplemented with chloramphenicol.

\begin{tabular}{llcc}
\multicolumn{1}{c}{ Lysate } & Indicator strain & $\begin{array}{c}\text { No. of } \\
\text { p.f.u. } \mathbf{m l}^{-1}\end{array}$ & $\begin{array}{c}\text { No. of } \\
\text { Mucts62 }\end{array}$ \\
& JM260 & $3 \times 10^{9}$ & - \\
DM1/D108-1 & JM260 & $10^{7}$ & - \\
& 20D3 & $2.5 \times 10^{9}$ & $2 \cdot 5 \times 10^{6}$ \\
& 20D3(Mucts62) & $1 \times 10^{8}$ & $1.5 \times 10^{5}$ \\
& & $3 \times 10^{8}$ & $1 \times 10^{5}$
\end{tabular}

-, Not applicable. 


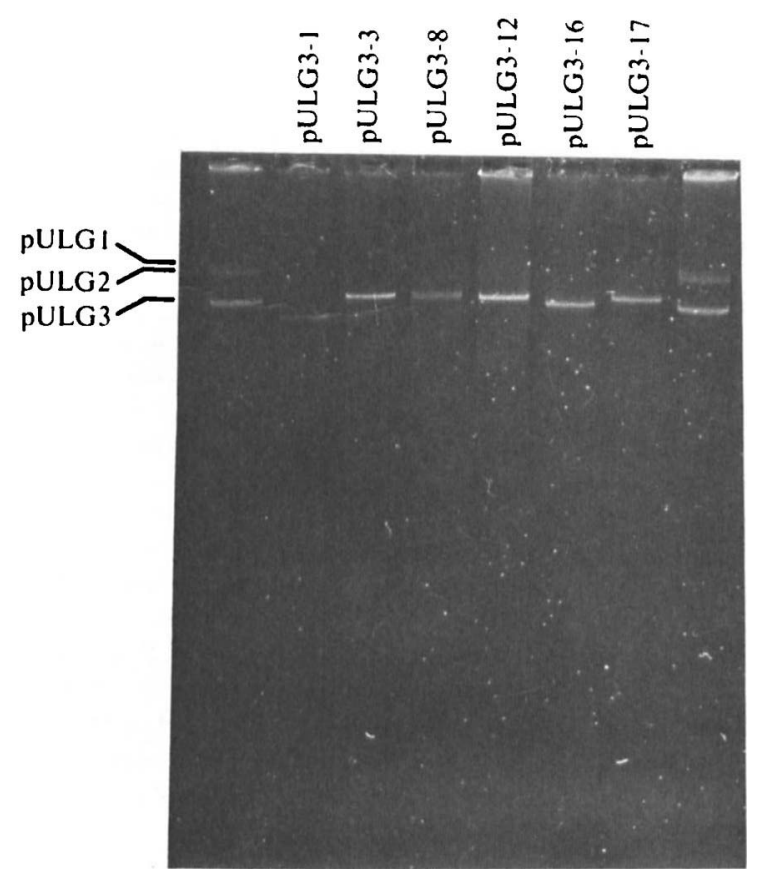

Fig. 1. Plasmids of E. uredovora 20D3 (extreme left and right) and of six different $E$. coli CSH23(pULG3 : :D108-1) strains. The DNA was extracted by the procedure of Kado \& Liu (1981).

the integration of mini-D108-1 appeared at a frequency of $10^{-3}$ p.f.u. ${ }^{-1}$. The presence of the D108-1 prophage in the $\mathrm{Cm}^{r}$ transductants was confirmed by showing that these strains had D108 immunity and produced only Mucts62 infectious particles. All transductants tested retained the plasmids of the parental strain (data not shown).

\section{Plasmid-mediated transfer of D108-1 to E. coli}

20D3(Mucts62)(D108-1) was grown in L broth at $32^{\circ} \mathrm{C}$ to a density of $2 \times 10^{8}$ bacteria ml $^{-1}$ and heated for $20 \mathrm{~min}$ at $42{ }^{\circ} \mathrm{C}$ to induce the transposition of D108-1. The transferability of the plasmids labelled by D108-1 was determined by looking for the transfer of the $\mathrm{Cm}^{\mathrm{r}}$ marker to a plasmid-free E. coli recipient strain. The $\mathrm{Sm}^{\mathrm{r}} \mathrm{JMM} 260$ strain was chosen as recipient because of its $h s r$ genotype (which prevents restriction of unmodified incoming DNA) and its resistance to $\mathrm{Mu}$ (which prevents transduction of $\mathrm{Cm}^{\mathrm{r}}$ by the D108-1 genomes packaged in Mu capsids). $\mathrm{Cm}^{r} \mathrm{Sm}^{r}$ transconjugants were isolated at a frequency of about $10^{-7}$ per donor cell and 20 of these were purified and tested for the transferability of their $\mathrm{Cm}^{r}$ traits to E. coli strain CSH 23 at $32{ }^{\circ} \mathrm{C}$ (this temperature was used to repress the D108 function). All clones were able to donate the $\mathrm{Cm}^{\mathrm{r}}$ marker at frequencies ranging from $10^{-9}$ to $2 \times 10^{-5}$ per donor cell.

\section{Plasmid content of the E. coli $\mathrm{Cm}^{r}$ transconjugants}

The plasmids of E. uredovora 20D3 and six E. coli $\mathrm{CSH} 23 \mathrm{Cm}^{r}$ transconjugants were extracted by the method of Kado \& Liu (1981) and their electrophoretic mobilities were compared (Fig. 1). $20 \mathrm{D} 3$ contained three plasmids with molecular sizes of $260 \mathrm{~kb}$ (pULG1), $216 \mathrm{~kb}$ (pULG2) and $88 \mathrm{~kb}$ (pULG3). The $\mathrm{CSH} 23 \mathrm{Cm}^{\mathrm{r}}$ transconjugants each carried one plasmid that migrated differently in each clone and was smaller than pULG1 and pULG2. Four molecules have mobilities close to the one expected for a pULG3 : :D108-1 plasmid. Homology between pULG3 and these plasmids was investigated by comparing the EcoRI digestion patterns of the DNA extracted by alkaline lysis (Birnboim \& Doly, 1979) from 20D3 and CSH23 $\mathrm{Cm}^{\mathrm{r}}$ clones. This extraction method resulted in the isolation of pULG3 largely devoid of the other plasmid DNA from strain E. uredovora 20D3. A similar result was obtained using the method of Currier \& 


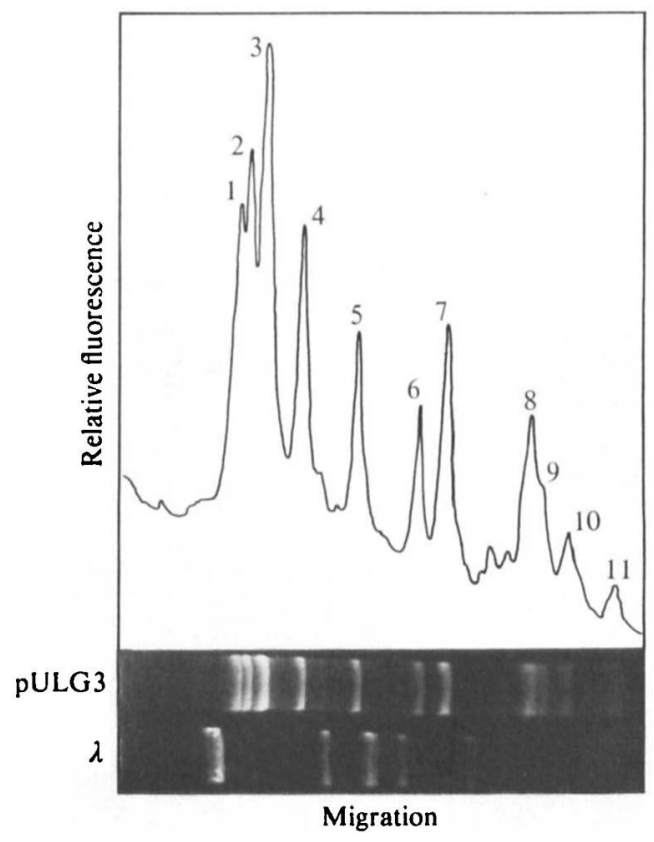

Fig. 2. Restriction of pULG3 with EcoRI and scanning of the pattern. The plasmids were purified according to Currier \& Nester (1976). $\lambda$ DNA digested with EcoRI was used as a size standard. The areas under peaks 3,7 and 8 were found to be twice the expected values. Therefore, each of these peaks must correspond to two digestion fragments that have similar electrophoretic mobilities.

Nester (1976), if no care was taken during the shearing and denaturation/renaturation steps. The EcoRI digest of pULG3 isolated from 20D3 is composed of 11 bands (Fig. 2) The microdensitometry analysis indicated that bands 3,7 and 8 correspond to doublets. pULG3 thus contained 14 sites for EcoRI. The molecular size of pULG3 as deduced from the restriction fragments was $86.1 \pm 2.5 \mathrm{~kb}$. The EcoRI restriction patterns of pULG3 and the plasmids carrying the $\mathrm{Cm}^{\mathrm{r}}$ marker (Fig. 3) show that 10 electrophoretic bands were common to pULG3 and each of the $\mathrm{Cm}^{\mathrm{r}}$ plasmids. This clearly identified pULG3 as a conjugative plasmid. The different $\mathrm{Cm}^{\mathrm{r}}$ plasmids showed the same additional fragment of $3 \mathrm{~kb}$ that corresponds to a $3 \mathrm{~kb}$ EcoRI fragment present in D108-1 DNA. Moreover, the replacement of one of the EcoRI fragments of pULG3 by two 'junction' fragments was detected in some of the DNA preparations. The different $\mathrm{Cm}^{\mathrm{r}}$ plasmids, as deduced from their EcoRI patterns, ranged between 80 and $100 \mathrm{~kb}$ in size. A molecular size of $96 \mathrm{~kb}$ could be expected for pULG3 with a single precise insertion of D108-1. The heterogeneity in the size of the pULG3::D108-1 plasmids is not surprising, however, since it was previously reported that transposition of $\mathrm{Mu}$ from one replicon to another may result in rearrangements (insertion or deletion) of the recipient replicon (Chaconas et al., 1981; Coelbo et al., 1980; Maynard-Smith et al., 1980). The transposition of D108-1 to random locations in pULG3, as well as the rearrangements induced by the mini-phage (Toussaint et al., 1981), could be related to the differences in transfer frequency of the various pULG3 ::D108-1 plasmids.

\section{Determination of the incompatibility group of $p U L G 3$}

The incompatibility group of pULG3 was investigated using pULG3-8, one of the pULG3 : :D108-1 plasmids that transferred most efficiently. The molecular size of pULG3-8 was estimated to be $96 \mathrm{~kb}$. Members of IncB, IncC, IncFI, IncFII, IncFIV, IncH 1, Incl $\alpha$, IncI2, IncI $\delta$, IncM or IncP incompatibility groups (see Table 1) were introduced in JMM260(pULG38 ) and the segregation of the markers of both plasmids was investigated. pULG3-8 could stably coexist with all the plasmids tested except R69-2, which belongs to the IncM group. Member- 


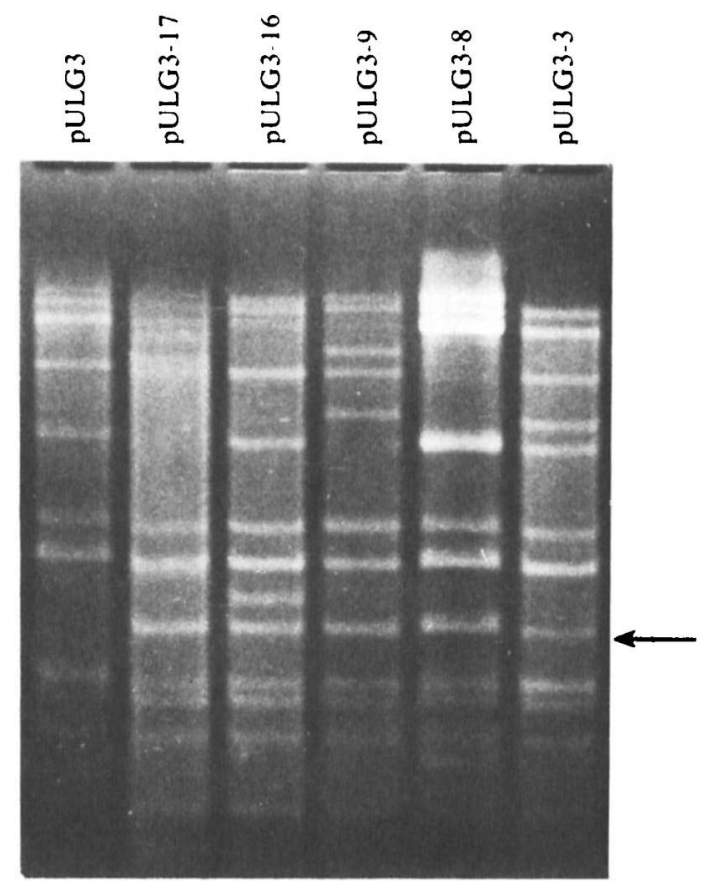

Fig. 3. EcoRI restriction of different pULG3 : :D108-1 plasmids compared with EcoRI restriction of pULG3 (track 1). The plasmids were prepared by a method derived from that of Birnboim \& Doly (1979), as described in Methods. The arrow indicates the characteristic internal EcoRI fragment of D108-1.

Table 3. Incompatibility between IncM plasmids and pULG3-8

Clones were tested as described in Methods. The markers used for the selection of the transfer and to detect segregation of the plasmids were $\mathrm{Km}^{\mathrm{r}}$ for $\mathrm{R} 69-2$, $\mathrm{Tc} \mathrm{c}^{\mathrm{r}}$ for $\mathrm{R} 135$ and $\mathrm{Cm}^{\mathrm{r}}$ for pULG3-8. Symbols * and $\dagger$ denote the resident and incoming plasmid, respectively.

\begin{tabular}{|c|c|c|c|c|}
\hline \multirow[b]{2}{*}{ Strain } & \multirow[b]{2}{*}{$\begin{array}{c}\text { No. of } \\
\text { clones tested }\end{array}$} & \multicolumn{3}{|c|}{ No. of clones which lost the marker of: } \\
\hline & & $\begin{array}{l}\text { The resident } \\
\text { plasmid }\left({ }^{*}\right)\end{array}$ & $\begin{array}{l}\text { The incoming } \\
\text { plasmid }(\dagger)\end{array}$ & $\begin{array}{l}\text { Both } \\
\text { plasmids }\end{array}$ \\
\hline $\begin{array}{l}\text { C600(R69-2)*(R135)† } \\
\text { C600(R69-2) } \\
\text { C600(R135) }\end{array}$ & $\begin{array}{r}180 \\
20 \\
20\end{array}$ & $\begin{array}{r}151 \\
0 \\
-\end{array}$ & $\frac{8}{0}$ & $\frac{1}{-}$ \\
\hline $\begin{array}{l}\text { JMM260(pULG3-8)*(R69-2)† } \\
\text { JMM260(pULG3-8) } \\
\text { JMM260(R69-2) }\end{array}$ & $\begin{array}{l}60 \\
20 \\
20\end{array}$ & $\begin{array}{r}27 \\
0 \\
-\end{array}$ & $\frac{8}{0}$ & $\frac{0}{-}$ \\
\hline $\begin{array}{l}\text { C600(R69-2)*(pULG3-8) } \dagger \\
\text { C600(R69-2) } \\
\text { C600(pULG3-8) }\end{array}$ & $\begin{array}{l}60 \\
20 \\
20\end{array}$ & $\begin{array}{r}5 \\
0 \\
-\end{array}$ & $\frac{13}{0}$ & $\frac{0}{-}$ \\
\hline $\begin{array}{l}\text { CSH23(pULG3-8)*(R135) } \dagger \\
\text { CSH23(pULG3-8) } \\
\text { CSH23(R135) }\end{array}$ & $\begin{array}{r}115 \\
20 \\
20\end{array}$ & $\begin{array}{r}11 \\
0 \\
-\end{array}$ & $\frac{23}{0}$ & $\frac{0}{-}$ \\
\hline
\end{tabular}

ship of pULG3 in the IncM family was further supported by the introduction of pULG3-8 into C600(R69-2) or the transfer of R135, another IncM plasmid, into CSH23(pULG3-8) (Table 3). R69-2 and R135 were also transferred to $E$. uredovora 20D3. Both plasmids were unstable in this host and were lost (in the absence of selection pressure) at a frequency of $50 \%$ to $95 \%$. Attempts to isolate 20D3 strains that maintained R69-2 or R135 stably and were cured of pULG3 were 
unsuccessful. The difference in the behaviour of these plasmids in $E$. coli and $E$. uredovora is under investigation.

The IncM plasmids form a large group in the enterobacteriaceae (Hedges et al., 1973; Richards \& Datta, 1979). These plasmids have molecular sizes of 65 to $105 \mathrm{~kb}$ and were mostly isolated from the genera Proteus, Klebsiella and Serratia (Jacob et al., 1977). Most of them carry transposable elements which determine resistance to antibiotics (Chabbert et al., 1979).

Transfer of any of the pULG3 : :D108-1 plasmids from E. uredovora to E. coli did not provide the recipient with any detectable function other than resistance to chloramphenicol. This suggested that pULG3 did not code for the bacteriocin produced by $E$. uredovora 20D3. Recent results indicate that the genetic determinants of this bacteriocin are located in the host chromosome (M. Thiry \& G. Thiry, unpublished results). Experiments are in progress to determine whether the transfer system of pULG3 can mobilize the chromosome of $E$. uredovora.

Thanks are due to Drs L. Ledoux, A. Toussaint, M. Mergeay and M. Thiry for stimulating discussions, to Dr $P$. Pohl for providing the collection of incompatibility plasmids and to M. Zavanelli for improvement of the English of this manuscript. This research was pursued in a Centre IRSIA and partly supported by grant from Actions de Recherches Concertées en Biologie Végétale (80-85-18). G. T. is a fellow of the Institut pour l'Encouragement de la Recherche Scientifique dans l'Industrie et l'Agriculture (IRSIA).

\section{REFERENCES}

APPleyard, R. K. (1954). Segregation of lambda lysogenicity during bacterial recombination in Escherichia coli K12. Genetics 39, 429-439.

BACHMANN, B. J. (1983). Linkage map of Escherichia coli K12, edition 7. Microbiological Reviews 47, 180230.

Birnboim, H. C. \& Doly, J. (1979). A rapid alkaline extraction procedure for screening recombinant plasmid DNA. Nucleic Acids Research 7, 1513-1523.

Buchanan, R. E. \& Gibbons, N. E. (editors) (1974). Bergey's Manual of Determinative Bacteriology, 8th edn. Baltimore: Williams \& Wilkins.

BukHari, A. I. \& LJUNGQuist, E. (1977). Bacteriophage $\mathrm{Mu}$ : methods for cultivation and use. In $D N A$ Insertion Elements, Plasmids and Episomes, pp. 749756. Edited by A. I. Bukhari, J. A. Shapiro \& S. L. Adhya. Cold Spring Harbor, New York: Cold Spring Harbor Laboratory.

Chabbert, Y. A., Roussel, A., Witchitz, J. L., Sanson-Le-Pors, M.-J. \& Courvalin, P. (1979). Restriction endonuclease generated patterns of plasmids belonging to incompatibility groups $\mathrm{I} 1, \mathrm{C}$, $\mathrm{M}$, and $\mathrm{N}$; application to plasmid taxonomy and epidemiology. In Plasmids of Medical, Environmental and Commercial Importance, pp. 183-193. Edited by K. N. Timmis \& A. Pühler. Amsterdam: Elsevier/ North-Holland Biomedical Press.

Chaconas, G., Harshey, R. M., Sarvetnick, J. \& BukHari, A. I. (1981). Predominant end-products of prophage Mu DNA transposition during the lytic cycle are replicon fusions. Journal of Molecular Biology 150, 341-359.

Coelbo, A., Leach, D., Maynard-Smith, S. \& SYMONDS, N. (1980). Transposition studies using a ColEl derivative carrying phage Mu. Cold Spring Harbor Symposia on Quantitative Biology 43, 12471255.

CURRIER, T. C. \& Nester, E. W. (1976). Isolation of covalently closed circular DNA of high molecular weight from bacteria. Analytical Biochemistry 76, $431-441$.
Datta, N. (1979). Plasmid classification: incompatibility grouping. In Plasmids of Medical, Environmental and Commercial Importance, pp. 3-12. Edited by K. N. Timmis and A. Pühler. Amsterdam: Elsevier/ North-Holland Biomedical Press.

Faelen, M., Résibois, A. \& Toussaint, A. (1978). Mini-Mu: an insertion element derived from temperate phage Mu-1. Cold Spring Harbor Symposia on Quantitative Biology 43, 1169-1177.

FaElen, M., Toussaint, A., LefèbVRe, N., Mergeay, M., Braipson-Thiry, J. \& ThIRY, G. (1981). Certaines souches de Erwinia sont sensibles au bactériophage Mu. Archives internationales de physiologie et de biochimie 89, 55.

Gill, G. S., Hull, R. C. \& Curtiss, R., III (1981). Mutator bacteriophage D108 and its DNA; an electron microscopic characterization. Journal of Virology 37, 420-430.

Hedges, R. W., Datta, N., Coetzee, J. \& Dennison, S. (1973). R factors from Proteus morganii. Journal of General Microbiology 77, 249-259.

Howe, M. M. (1973). Prophage deletion mapping of bacteriophage $\mathrm{Mu}-1$. Virology 54, 93-101.

Hull, R. A., Gill, G. S. \& Curtiss, R., III (1978). Genetic characterization of Mu-like bacteriophage D108. Journal of Virology 27, 513-518.

Jacob, A. E., Shapiro, J. A., Yamamoto, L., Smith, D. I., Cohen, S. N. \& Berg, D. (1977). Plasmids studied in Escherichia coli and other enteric bacteria. In DNA Insertion Elements, Plasmids and Episomes, pp. 607-638. Edited by A. I. Bukhari, J. A. Shapiro \& S. L. Adhya. Cold Spring Harbor, New York: Cold Spring Harbor Laboratory.

KADO, C. I. \& LIU, S. T. (1981). Rapid procedure for detection and isolation of large and small plasmids. Journal of Bacteriology 145, 1365-1373.

McDonell, M. W., Simon, M. N. \& Studier, F. W. (1977). Analysis of restriction fragments of T7 DNA and determination of molecular weights by electrophoresis in neutral and alkaline gels. Journal of Molecular Biology 110, 119-146. 
Maynard-Smith, S., Leach, D., Coelbo, A., Carey, J. \& SYMONDS, N. (1980). The isolation and characteristics of plasmids derived from the insertion of MupAp1 into pML2: their behaviour during transposition. Plasmid 4, 34-50.

MilleR, J. H. (1972). Experiments in Molecular Genetics. Cold Spring Harbor, New York: Cold Spring Harbor Laboratory.

Novick, R. P., Clowes, R. C., Cohen, S. N., CuRtiss, R., III, DatTA, N. \& Falkow, S. (1976). Uniform nomenclature for bacterial plasmids: a proposal. Bacteriological Reviews 40, 168-189.

van de Putte, P., Cramer, S. \& Giphart-Gassler, M. (1980). Invertible DNA determines host specificity of bacteriophage Mu. Nature, London 286, 218222.

Résibois, A., Toussaint, A., VAN Gijsegem, F. \& FAelen, M. (1981). Physical characterization of mini-Mu and mini-D108. Gene 14, 103-113.

RichARDS, H. R. \& DATTA, N. (1979). Reclassification of incompatibility group L (IncL) plasmids. Plasmid 2, 293-295.

THIRY, G. (1984). Plasmids of the epiphytic bacterium Erwinia uredovora. Journal of General Microbiology 130, 1623-1631.
Thiry-Braipson, J., Calberg-BacQ, C.-M., D'AgosTINO, C. \& LEDOUX, L. (1982). Electron microscopy and biological study of macromolecular bacteriocins produced by Erwinia uredovora and Serratia plymuthicum. Archives internationales de physiologie et de biochimie 90, 75.

Toussaint, A. \& Résibois, A. (1983). Phage Mu: transposition as a life-style. In Mobile Genetic Elements, pp. 105-158. Edited by J. A. Shapiro. New York: Academic Press.

Toussaint, A. \& Schoonejans, E. (1982). Production and modification of $\mathrm{Mu}(\mathrm{G}-)$ phages particles in Escherichia coli $\mathrm{K} 12$ and Erwinia. Genetical Research 41, 145-154.

Toussaint, A., Faelen, M. \& Résibois, A. (1981). Chromosomal rearrangements induced by mini-Mu and mini-D108. Mini review and new data. Gene 14, 115-119.

Toussaint, A., Faelen, M., Desmet, L. \& Allet, B. (1983). The products of gene $A$ of the related phages $\mathrm{Mu}$ and D108 differ in their specificities. Molecular and General Genetics 190, 70-79. 